\title{
ETHNOBIOLOGY OF HIGH ALTITUDE HIMALAYAN COMMUNITIES IN DISTRICT CHAMOLI: A CONSERVATION PERSPECTIVE
}

\author{
V.P. Bhatt \\ Scientist, Herbal Research and Development Institute, Gopeshwar, Chamoli Garhwal, Uttar Pradesh 246401, India
}

\begin{abstract}
Chamoli is a border district of Uttarakhand or U.P. Himalaya having one tribal community, the Bhotia, inhabiting the high mountainous regions in Block Joshimath and the ethnic groups Khasas and Doms inhabiting the entire larger montane and submontane regions. The former race has basically and traditionally been associated with the practice of nomadism, weaving, agriculture and pastoral nomadism since time immemorial. The latter group is inhabiting in remote parts of the district, though engaged mainly in agriculture and pastoral activities, are to some extent, involved traditionally in the practices of nomadism, weaving and pastoral nomadism unlike the tribal community. These people live in and survive very drastic climatic and environmental conditions and have close cultural and social relations with the surrounding nature and natural resources. Poaching of wild animals and collection of herbs from the wild are being practised unsustainably and the intensity of such practices is on the increase. The reasons behind these ecologically damaging activities in the Himalayan belt are (a) illiteracy and lack of knowledge of sustainable environmental education and (b) extremely poor economic condition of most families. In the present investigation some seriously affected floral and faunal species along with their ethnobiological observations and innovative mitigation measures for their conservation are analysed.
\end{abstract}

\section{Key words}

Ethnobotany, ethnozoology, U.P. Himalaya, Bhotia, ethnic community, nomadism, pastoralism, poaching

A - Agriculture
E - Ethnic
Ethbny - Ethnobotany
M - Marcha
P - Pastoralism
PN - Pastoral nomadism
T - Tolcha
W - Weaving

\section{Introduction}

Chamoli is the second largest district in the state of Uttar Pradesh with an area of 9130 sq. $\mathrm{km}$. having a population of about 40 people per sq.km. as compared to 377 for the state (Anonymous, undated). However, some parts of Chamoli have now been included in a newly announced and established district of Uttarakhand (Rudraprayag), but the boundary is yet to be demarkated. For the purpose of present investigation, old existing records regarding geography of District Chamoli are given here.

Received 12 December 1998;

\section{Abbreviations}

\author{
$\mathrm{Bh}$ - Bhotia \\ En - English \\ Ethzogy - Ethnozoology \\ $\mathrm{N}$ - Nomadism \\ PIT - Private/personal illegal trade \\ R-H - Road-head \\ TO - Traditional occupation
}


soil receiving very low annual precipitation. The dominant human community in the area is the Bhotia community (Tolcha and Marcha are two different types) migrating during summer to Mana and Niti Valleys in Joshimath Block, which are rich in aromatic plants. Other zones ainclude wet temperate and alpine regions having green meadows (Bugyal) receiving high degree of annual rainfall and chiefly inhabited by ethnic group, Khasas and Doms.

There are many similarities in the traditional practices adopted by the tribal and ethnic communities inhabiting the remote regions. However, the degree of similarities differs both in time and space. Despite the fact that this part of U.P. Himalaya unlike other regions of the Himalaya is well known for its rich natural repositories of wild flora and fauna and cultural diversity, the inner remote parts are one of the most neglected and backward regions in the world. The people here are mostly illiterate but traditionally rich in social and cultural rituals and occupy a very small ecological niche for their survival. Inspite of their roundthe-clock engagements in accomplishing domestic duties, they face high degree of hardship to earn their livelihood. They live in a situation where resources are scattered and are accessible only in certain spatial pockets. Their problem is not simply one of gaining spatial access to resources through active movement, but also of acquiring them as they become available only at certain seasons (Hoon, 1996).

Traditionally these people have associated with subsistence cultivation of potato (Solanum tuberosum), Wogal (Fagopyrum esculentum), Phaphar (Fagopyrum tataricum) Wheat (Triticum aestivum), Rice (Oryza sativa), Ramdana/Chaulai (Amaranthus paniculatus) and traditional cultivation of food crops like Koda (Eleusine coracana) and Jhangora (Penicum frumentoceum). Pastoralism and nomadism are also traditional adaptations commonly accomplished by both tribal and ethnic groups. However, there is a considerable difference between tribal nomadism and ethnic nomadism as the former group moves to some larger distance with all the family members mainly for agriculture, while the ethnic people migrate to a shorter distance only with livestocks and either with a partner (husband/wife) or alone mainly for pastoralism. Pastoral nomadism, though decreasing, is also shared equally by the members derived from both the ethnic and tribal families.

\section{Material and Methods}

The standard methodology as given by Jain (1963) was adopted during the study. Four blocks in District Chamoli i.e., Dasholi, Dewal, Ghat and Joshimath were surveyed randomly from 1993 to 1998 with the following objectives:

a. to identify the inhabiting groups as to which genetic races they belong.

b. to record the ecological niche of these races in form of the distance from road-head $(\mathrm{R}-\mathrm{H})$ and interactions and relations with the locally available natural biological resources.

c. to observe the traditional occupation (TO) of these communities like agriculture (A), weaving (W), pastoralism (P-grazing of livestocks and the distance from the agriculture village), nomadism ( $\mathrm{N}$ - designating the seasonal movement of people and their livestocks in mountainous areas (Hoon, 1996)) and pastoral nomadism (PN- refers to the pastoral nomad that do not occupy permanent dwellings, but live in tents or semi-permanent structures throughout the year).

d. to measure the frequency and distribution of traditional occupation and

e. to record the ethnobotanical and ethnozoological data and their impacts on the conservation of biodiversity in the region.

The informations pertaining to ethnobotany (Ethbny; folk uses of plant/plant(s) parts) and ethnozoology (Ethzogy; folk uses of animal/animal(s) parts) are based on the results of interrogation, questionnaires and interactions with the locals, herbspecialists (persons using both animal and plant parts), pastoralists, herb-vendors, Vaidyas (traditional herbal doctors) and old-experienced persons in pastoral nomadic communities (Palsi). The estimated extent of pressure of private/personal illegal trade (PIT) and folk uses of animal(s)/plant(s) parts on the survival of some seriously concerned species is given in terms of approximate percent in tables 2 and 3 . The plus $(+)$ and minus (-) symbols indicates whether a particular species is being used or not, respectively, under the given head.

The approximate percent of PIT, Ethzogy and Ethbny is given within the parenthesis. The correlation between PIT $\%$ and Ethzogy $\%$ and Ethbny $\%$ is based on the physical observations taken during the field study; 100 is taken as standard measure (\%). The \% of PIT is (0) when a particular species is not traded in anyway (or when there are no economic criteria involved) while at the same time the \% for its Ethzogy/Ethbny is $+(100)$ because it is used only locally and the pressure of the latter upon a particular species is $100 \%$. This simply denotes the degree and extent of human pressures on the existence of the given species. Latin names are provided for every species alongwith English (En), Ethnic (E), Bhotia (Bh; when both Tolcha and Marcha groups have common names), Tolcha (T) and Marcha (M) names. The altitude in feet above mean sea level of possible occurrence of some species studied has also been mentioned.

\section{Observations}

Mainly a tribal community Bhotia and two ethnic groups Khasas and Doms are the inhabitants in the high altitude of District Chamoli. The Bhotias are scattered in the lower valley in blocks 
Dasholi, Ghat, Joshimath, Karanprayag and Nandprayag where they live during winter season and as and when the summer approaches these people migrate to higher elevations and settle in two valleys namely Mana and Niti, both in block Joshimath (Table 1). The Bhotia of Mana Village in Mana Valley and Niti, Gamsali and Bampa in Niti Valley are popularly known as Marcha who amongst themselves speak a dialect of Tibetan origin while Bhotias in villages like Jelum, Malari, Reni, Lata, Dronagiri, Kaga, Rweeng, Garpeg and Jumma all in Niti Valley are known as Tolcha speaking Garhwali, a dialect spoken throughout the district. Both the groups are however, followers of the Hindu religion. By and large much of the landscape is occupied by the ethnic populations in the district.

It is generally believed and considered that only Bhotia people live in remote regions, but Table 1 clearly indicates that there is only one summer tribal village Dronagiri in the district which is $14 \mathrm{~km}$. away from the road-head. Owing to such a long and inaccessible travelling distance, half of the total families ( below the poverty line) migrate to this village. There are many ethnic villages which are inaccessible. The villages in Dewal Block except Van and Vank are situated more than $30 \mathrm{~km}$. from the roadhead (Table 1). It has been observed that on the one hand building of roads in high Himalaya has made outsiders accessible to reach these villages but on the other hand influencing negatively on the original Himalayan culture and old sustainable, social and ecological systems. Constructions in the inner sensitive Himalaya are also the main causes for habitat destruction. The systems adopted by the people in remote regions like long-distance villages in Dewal Block, that are remote and cut off from constructions and road access, are ecologically, socially and culturally more stable and sustainable. These people still practice regulated and experienced conservation principles.

While agriculture is the main traditional occupation of ethnic groups, weaving has been a patronymic business of tribal people (Table 1) and usually includes weaving of well-designed carpet (Dan), woollen blanket (Pankhi), a woollen quail (Lawa) a woollen quilt (Thulma) and other woollen clothes. When the Bhotia people migrate to the higher altitudes in summer they engage in subsistence cultivation of food crops like Phaphar (Fagopyrum tataricum), Wogal (Fagopyrum esculentum), Potato (Solanum tuberosum) and Rajma/Chaimi (Phaseolus vulgaris), while the ethnic groups cultivate Ramdana/Chuwa (Amaranthus paniculatus), Genhu (Triticum aestivum), Dhan/ Shatti (Oryza sativa), Koda (Eleusine coracana), Jhangora (Panicum frumentoceum) and various types of pulses like Urd (Phaseolus mungo). Ploughing in the Bhotia group is assisted either by a pair of bullocks or bulls (single and/or inpairs) while in ethnic group it is carried out either by a pair of bullocks or occassionally by a man or woman.

Some people from ethnic groups situated in remote regions especially in Dewal Block have also been found engaged, to some extent, in the business of weaving, particularly woollen clothes like rough carpet and Thulma (a soft woollen quilt), an armless frock-coat (Dokho; made for nomadic people) and quail (Lawa). By and large pastoral life is equally shared by people of both the groups. The percent of pastoral nomadism in ethnic community is larger than the tribal group. This is on account of construction of approach roads to the tribal villages resulting in the easy access of materials directly to the village site. The tribals opine that the life of a pastoral nomad is tough as it involves natural and artificial risks. The pastoral nomads from ethnic groups were more positive about their livelihood and were willing to continue without the disturbance of persons from the government and other non-government organisations.

Nomadism has been one of the main traditional occupations not only practised by the tribal group but also adopted by the ethnic groups. However, on the basis of the nature of migration it can be divided into two kinds.

Ethnic nomadism: This is traditionally adopted by the ethnic groups and defined as "migration of some members of a family mostly men or both men and women with their livestock to shorter distance but towards higher elevations with all the necessary domestic cooking pots, ration, beddings, clothings etc. They do not have permanent dwellings in the summer villages (Maroda, Channi) but semi-permanent huts (Chappar) with stone wall and tight covering (roof) of Oak wood. Both the livestock and family members live under the same roof. Though pastoralism for organic manure and for production of Ghee (clarified butter) remains the main objectives of ethnic nomadism, agriculture is also practised by some members and mixed food and vegetable crops cultivated include Potato, Ramdana and some fruit crops like Akhrot/Ankhod (Juglans regia), Sheb/shyo (Pyrus amygdalus), Naashpati (Pyrus communis) and Baddam (Pyrus malus). Making various types of baskets from Ringal/ Ningalo (Arundinaria species) is also an economic part of ethnic nomadism.

Tribal nomadism: This differs in many ways to ethnic nomadism. Tribals have permanent houses with all the basic needs in both the summer and winter villages. Some years ago all the members used to go to summer villages but now only some members migrate to the high altitudes because of low education facility in Bhotia summer villages. Mainly primary education facility is available. Tribal nomadism is basically performed for cultivation of subsistence agriculture food crops. The people are so busy during summer months in agriculture farming that they hardly get time for weaving, which is mainly executed during dormant winter leisure months.

The aim of both ethnic and tribal nomadism is maximum utilization of natural resources both in time and space. Collection of herbs in the wild and poaching has been one of the main income generating sources for tribal and ethnic communities since long. 
Collection of herbs for trade is adopted chiefly by the Bhotia people while hunting of wild animals is commonly shared by both the groups (Tables $2 \& 3$ ). While members of the ethnic community, when in high altitude regions, collect medicinal herbs only for ethnobotanical purposes, the tribals collect them both for trade and ethnobotanical purposes; though the pastoral nomadic community derived from ethnic groups also collect medicinal plants like tribal people for both trade and ethnobotanical uses. There are onleight out of 21 plants studied that are now collected for ethnobotany (Table 3 ). Similarly, there are two animal taxa, out of 10 studied that have only ethnozoological uses (Table 2). This study clearly indicates that both private/personal illegal trade (PIT) and ethnobiological activities are equally responsible for reduction in the numbers of floral and faunal species in the Himalaya.

\section{Discussion}

The mode of traditional subsistence and social culture among Himalayan indigenous communities has suffered a major set back due to many anthropocentric factors like increasing demographic expansion resulting in rural sprawl, growing commercialization and an alarming reduction in the availability of natural resources as a result of over-collection in the past. About two and half decades ago, these people had to depend only on locally grown food crops mentioned before and some wild available herbs such as Kandali (Urtica dioca), Kachnar/Queral (Bauhinia variegata), Polygonum species, Bethu (Chenopodium album) etc.; clothes worn were made locally. Only salt, molases and tea were items bought from the market. But now with the successful development of modern facilities like construction of roads, expansion in the number of shops in villages, and communication facilities, the indigenous social and cultural life are on the decline. One can easily experience the increase in the use of alcohol, a part of culture brought by the outsiders. The reduction in soil fertility of cultivated land has pushed more and more families each year to depend on ration from markets requiring ready money for the purchase of food grains and other essential commodities.

Owing to illiteracy among the people in remote regions and lack of any regular income generating sources, these people have long been associated with the collection of medicinal herbs in the wild and hunting of wild fauna. Naturally, the dependence of local communities on the forest for various resources cannot be ignored. But the process of commercialization of forest products should not be encouraged as it fosters competition between interests for access to resources of limited productivity and degradation of the environment (Horowitz, 1988).

Recently an agitation by the Bhotia community in Nanda Devi Biosphere Reserve (NDBR) area against violation of their communal rights is a living example of mismanagement of natural resources by the administrative agencies.
For most problems, conservation and sustainable use of natural biological resources could be a solution, but this depends on the understanding of the needs of the tribal community and the carrying capacity of the land. On the basis of field observations gathered over last 12 years, it seems certain that many wild animal and plant species in Uttarakhand Himalaya, particularly above $5000 \mathrm{ft}$. are under threat of extinction. Their existence and survival in future will depend on how long they can withstand the neverending exploitation. Only a few floral species can withstand and survive longer owing to their high regeneration and reproductive capacity.

Mr. Mohan Singh Chauhan, a progressive farmer at Gamsali, a village in Niti Valley, has cultivated Costus (Saussurea costus) on his land, successfully harvested 300 kilograms in November 1997 and stored it in an army camp near the village. The seeds were supplied under the Scheduled Tribe Development Planning Scheme 1991-92 by the Bheshaj Sangh at Joshimath. Poor planning by the government and nonexistence of cooperatives to sell cultivated medicinal plants has resulted in poor response of farmers to cultivate medicianl plants on their lands as alternate source rather than collecting from the wild. Currently, no farmer in Niti Valley is agreeable to cultivate herbs.

\section{Conclusion}

Though there is no clear-cut policy on conservation and sustainable use in our country, the only way to conserve biodiversity in the U.P. Himalaya and maintain the traditional practices of the tribals and ethnic communities of the region, a more holistic approach involving the communities, the local government and non-government organisations is required. Literacy is to be promoted with a strong emphasis on maintaining age-old customs and traditions and the use of sustainable harvest. Alternate methods of conserving wildlife like cultivation should be promoted and awareness on the effects of poaching or collecting of wild animals and plants on the ecosystem and on the economics of the community should be promoted.

\section{References}

Anonymous (undated). Chamoli ........ charms. EBD Education Pvt. Ltd. Dehradun. 56 pp.

Hoon,V. (1996). Living on the Move: Bhotiya of the Kumaon Himalaya, Ist edition. Sage Publication Ltd., New Delhi. 254 pp.

Horowitz, M.M. (1988). Anthropology and new development agenda. Development Anthropology Network. 6:13-17.

Jain,S.K. (1963). Plants used in medicine by the tribals of Madhya Pradesh. Bull. Reg. Res. Lab. Jaтmu. 1:126-128.

Shah,N.C. (1996). Ethnobotany of some well known Himalayan Compositae. In: Compositae, Biology, Utilization. P.D.S. Caligari and D.J.N. Hind (Eds.) Proceedings of the International Compositae conference, Kew, 1994. 2:415-422.

Shah, N.C. and M.C. Joshi (1971). An ethnobotanical study of the Kumaon region of India. Econ. Bot. 25(4):414-424.

Shah, N.C. and S.K. Jain (1988). Ethno-medico-botany of the Kumaon Himalaya, India. Soc. Pharmacology. 2(4): 359-380.

Singh, H., A. Saklani and Brij Lal (1990). Ethnobotanical observa- 
Table 1. Distribution and traditional occupation of ethnic and tribal communities in remote villages in District Chamoli

\begin{tabular}{|c|c|c|c|c|}
\hline Block & Village & Community & $\begin{array}{l}\text { Distance }(\mathbf{k m} .) \\
\text { from R-H }\end{array}$ & $\begin{array}{l}\text { Traditional Occupation (TO) } \\
\text { and percent }\end{array}$ \\
\hline Dasholi & $\begin{array}{l}\text { Patna } \\
\text { Irani } \\
\text { Kandey } \\
\text { Bamiyala }\end{array}$ & $\begin{array}{l}\text { Khasas \& Doms } \\
\text { Khasas \& Doms } \\
\text { Khasas \& Doms } \\
\text { Khasas \& Doms }\end{array}$ & $\begin{array}{l}18 \\
19 \\
5 \\
5\end{array}$ & $\begin{array}{l}\mathrm{A}(100)>\mathrm{P}(80)>\mathrm{PN}(8) \\
\mathrm{A}(100)>\mathrm{P}(80)>\mathrm{PN}(8) \\
\mathrm{A}(100)>\mathrm{P}(85)>\mathrm{PN}(2) \\
\mathrm{A}(100)>\mathrm{P}(85)>\mathrm{PN}(2)\end{array}$ \\
\hline Dewal & $\begin{array}{l}\text { Van } \\
\text { Vank } \\
\text { Ghes } \\
\text { Balan } \\
\text { Himni } \\
\text { Hermal } \\
\text { Saurigarh } \\
\text { Upthal } \\
\text { Kunwari } \\
\text { Bhara } \\
\text { Kandey }\end{array}$ & $\begin{array}{l}\text { Khasas \& Doms } \\
\text { Khasas \& Doms } \\
\text { Khasas \& Doms } \\
\text { Khasas \& Doms } \\
\text { Khasas \& Doms } \\
\text { Khasas \& Doms } \\
\text { Khasas \& Doms } \\
\text { Khasas \& Doms } \\
\text { Khasas \& Doms } \\
\text { Khasas \& Doms } \\
\text { Khasas \& Doms }\end{array}$ & $\begin{array}{l}6 \\
4 \\
40 \\
42 \\
47 \\
32 \\
34 \\
34 \\
47 \\
48 \\
46\end{array}$ & $\begin{array}{l}\mathrm{A}(100)>\mathrm{P}(80)>\mathrm{PN}(8) \\
\mathrm{A}(100)>\mathrm{P}(92)>\mathrm{PN}(8) \\
\mathrm{A}(100)>\mathrm{P}(80)>\mathrm{PN}(15)>\mathrm{W}(12)>\mathrm{N}(10) \\
\mathrm{A}(100)>\mathrm{P}(80)>\mathrm{PN}(15)>\mathrm{W}(12)>\mathrm{N}(10) \\
\mathrm{A}(100)>\mathrm{P}(82)>\mathrm{PN}(22)>\mathrm{W}(15)>\mathrm{N}(13) \\
\mathrm{A}(100)>\mathrm{P}(86)>\mathrm{PN}(17)>\mathrm{W}(13)>\mathrm{N}(12) \\
\mathrm{A}(100)>\mathrm{P}(80)>\mathrm{PN}(18)>\mathrm{W}(10)>\mathrm{N}(8) \\
\mathrm{A}(100)>\mathrm{P}(80)>\mathrm{PN}(18)>\mathrm{W}(9)>\mathrm{N}(8) \\
\mathrm{A}(100)>\mathrm{P}(88)>\mathrm{PN}(17)>\mathrm{W}(14)>\mathrm{N}(12) \\
\mathrm{A}(100)>\mathrm{P}(80)>\mathrm{PN}(25)>\mathrm{W}(17)>\mathrm{N}(15) \\
\mathrm{A}(100)>\mathrm{P}(82)>\mathrm{PN}(28)>\mathrm{W}(20)>\mathrm{N}(17)\end{array}$ \\
\hline Ghat & $\begin{array}{l}\text { Barwain } \\
\text { Ghuni } \\
\text { Kanol } \\
\text { Mokh } \\
\text { Ramni } \\
\text { Sutol }\end{array}$ & $\begin{array}{l}\text { Khasas \& Doms } \\
\text { Khasas \& Doms } \\
\text { Khasas \& Doms } \\
\text { Khasas \& Doms } \\
\text { Khasas \& Doms } \\
\text { Khasas \& Doms }\end{array}$ & $\begin{array}{l}8 \\
14 \\
14 \\
6 \\
14 \\
14\end{array}$ & $\begin{array}{l}\mathrm{A}(100)>\mathrm{P}(80)>\mathrm{N}(7)>\mathrm{PN}(4) \\
\mathrm{A}(100)>\mathrm{P}(80)>\mathrm{N}(5)>\mathrm{PN}(3) \\
\mathrm{A}(100)>\mathrm{P}(87)>\mathrm{N}(8)>\mathrm{PN}(5) \\
\mathrm{A}(100)>\mathrm{P}(88)>\mathrm{N}(5)>\mathrm{PN}(3) \\
\mathrm{A}(100)>\mathrm{P}(80)>\mathrm{N}(5)>\mathrm{PN}(4) \\
\mathrm{A}(100)>\mathrm{P}(87)>\mathrm{N}(8)>\mathrm{PN}(5)\end{array}$ \\
\hline Joshimath & $\begin{array}{l}\text { Niti } \\
\text { Gamsali } \\
\text { Bampa } \\
\text { Malari } \\
\text { Jelum } \\
\text { Dronagiri } \\
\text { Tolma } \\
\text { Suki } \\
\text { Lata } \\
\text { Raini } \\
\text { Subai } \\
\text { Mana }\end{array}$ & $\begin{array}{l}\text { Bhotia } \\
\text { Bhotia } \\
\text { Bhotia } \\
\text { Bhotia } \\
\text { Bhotia } \\
\text { Bhotia } \\
\text { Bhotia } \\
\text { a.Bhotia } \\
\text { b.Khasas \& Doms } \\
\text { Bhotia } \\
\text { Bhotia } \\
\text { Bhotia } \\
\text { Bhotia }\end{array}$ & $\begin{array}{l}6 \\
\text { R-H } \\
\text { R-H } \\
\text { R-H } \\
\text { R-H } \\
15 \\
3 \\
3 \\
2 \\
\text { R-H } \\
\text { R-H } \\
2 \\
\text { R-H }\end{array}$ & $\begin{array}{l}\mathrm{W}(100)>\mathrm{N}(80)=\mathrm{A}(80)>\mathrm{P}(73)>\mathrm{PN}(5) \\
\mathrm{W}(100)>\mathrm{N}(80)=\mathrm{A}(80)>\mathrm{P}(78)>\mathrm{PN}(3) \\
\mathrm{W}(100)>\mathrm{N}(80)=\mathrm{A}(80)>\mathrm{P}(70)>\mathrm{PN}(5) \\
\mathrm{W}(100)>\mathrm{N}(60)=\mathrm{A}(60)>\mathrm{P}(55)>\mathrm{PN}(3) \\
\mathrm{W}(100)>\mathrm{N}(60)=\mathrm{A}(60)>\mathrm{P}(55)>\mathrm{PN}(3) \\
\mathrm{W}(100)>\mathrm{N}(80)=\mathrm{A}(70)>\mathrm{P}(40)>\mathrm{PN}(5) \\
\mathrm{W}(100)>\mathrm{A}(80)>\mathrm{P}(60) \\
\mathrm{W}(100)>\mathrm{A}(80)>\mathrm{P}(70) \\
\mathrm{A}(100)>\mathrm{P}(90) \\
\mathrm{W}(100)>\mathrm{A}(89)>\mathrm{P}(73) \\
\mathrm{W}(100)>\mathrm{A}(95)>\mathrm{P}(88) \\
\mathrm{W}(100)>\mathrm{A}(95)>\mathrm{P}(80) \\
\mathrm{W}(100)>\mathrm{N}(80)=\mathrm{A}(80)>\mathrm{P}(69)>\mathrm{PN}(3)\end{array}$ \\
\hline
\end{tabular}

A-Agriculture; N-Nomadism; P-Pastoralism; PN- Pastoral nomadism; W-Weaving; R-H- Road-head; TO- Traditional occupation.

tions on some gymnosperms of Garhwal Himalaya, Uttar Pradesh India. Econ. Bot. 44(3): 349-354. 


$\begin{array}{llll}\text { Name of species } & \text { PIT } & \text { Ethzogy } & \text { Ethnozoology } \\ & (\%) & (\%) & \end{array}$

$(\%) \quad(\%)$

1. Muntiacus muntjak (Zimmermann)

$+(10)$ (En. Barking Deer; E.\&Bh. Kakhar) Upto $10,000 \mathrm{ft}$.

2. Panthera pardus (L.) (En.Panther; E.\&Bh. Bagh)

Upto 12,000 ft.

3. Uncia uncia (Schreber) (Snow Leopard; E.\&Bh. Bagh)

Alpine regions

4. Hystrix sp.

(En. Porcupine; E. \& Bh. Solo)

Upto 8,000 ft.

5. Moschus chrysogastar (Hodgson) (En. Musk Deer; Bh. Beena,

E. Kastura-mirg) 8,000-14,000 ft.

6. Hemitragus jemlahicus (H. Smith) (En. Himalayan Tahr; Bh.\&E. Thar) $6,000-10,000 \mathrm{ft}$

7. Naemorhedus goral (Hardwicke) (En. Himalayan Chamois; B. Ghurad; E. Ghwed) 4,000-9,000 ft.

8. Pseudois nayaur (Hodgson) (En.Blue-mountain sheep, E.\&Bh. Bharal) 10,000-16,000 ft.

$+(90)$

Trapped or shot mainly for flesh. The animal is skinned, coated with salt and sun dried for long time preservation for use as mat for meditation (Sandhya), decoration and to wrap or cover kettledrum, drum, and small tambourine and other musical instruments. The horns are also used to decorate houses

Though hunted mainly for skin trade, locally the nails, hair, skin, bones and fat are used in almost every tantra and mantra science conducted throughout the U.P. Himalaya.

There is a faith that keeping nails and hair inside a house keeps away evil spirits.

Though hunted mainly for skin trade, locally the nails, hair, skin, bones and fat are used in almost every tantra and mantra science conducted throughout the U.P. Himalaya.

There is a faith that keeping nails and hair inside a house keeps away evil spirits.

Farmers trap this animal when it feeds on crops at night Villagers smoke stone caves near villages to drive out the porcupines. The flesh is considered superior compared to culti vated goats and sheep. The thorns are used to make pen and in tantra and mantra rituals and especially used during the tonsure ceremonies. Thorns, when kept in a house, keeps away snakes and also used also for decoration.

Hunted/trapped for musk. Musk locally used as a life saving drug and in various religious rituals. Skin is either traded or locally used as saddle. Flesh is eaten. The hair is used to make pillows. Poachers kill both male and female Musk Deer.

Hunted only for flesh.

Mainly hunted for flesh. Skin and horns are locally traded and used for the same purposes as of Barking Deer.

Hunted for flesh. A long garment of sun dried flesh is made for use in off-season and sometimes traded locally. The skin is used in place of a mattress especially for aged suffering from cold, during the winter months. 


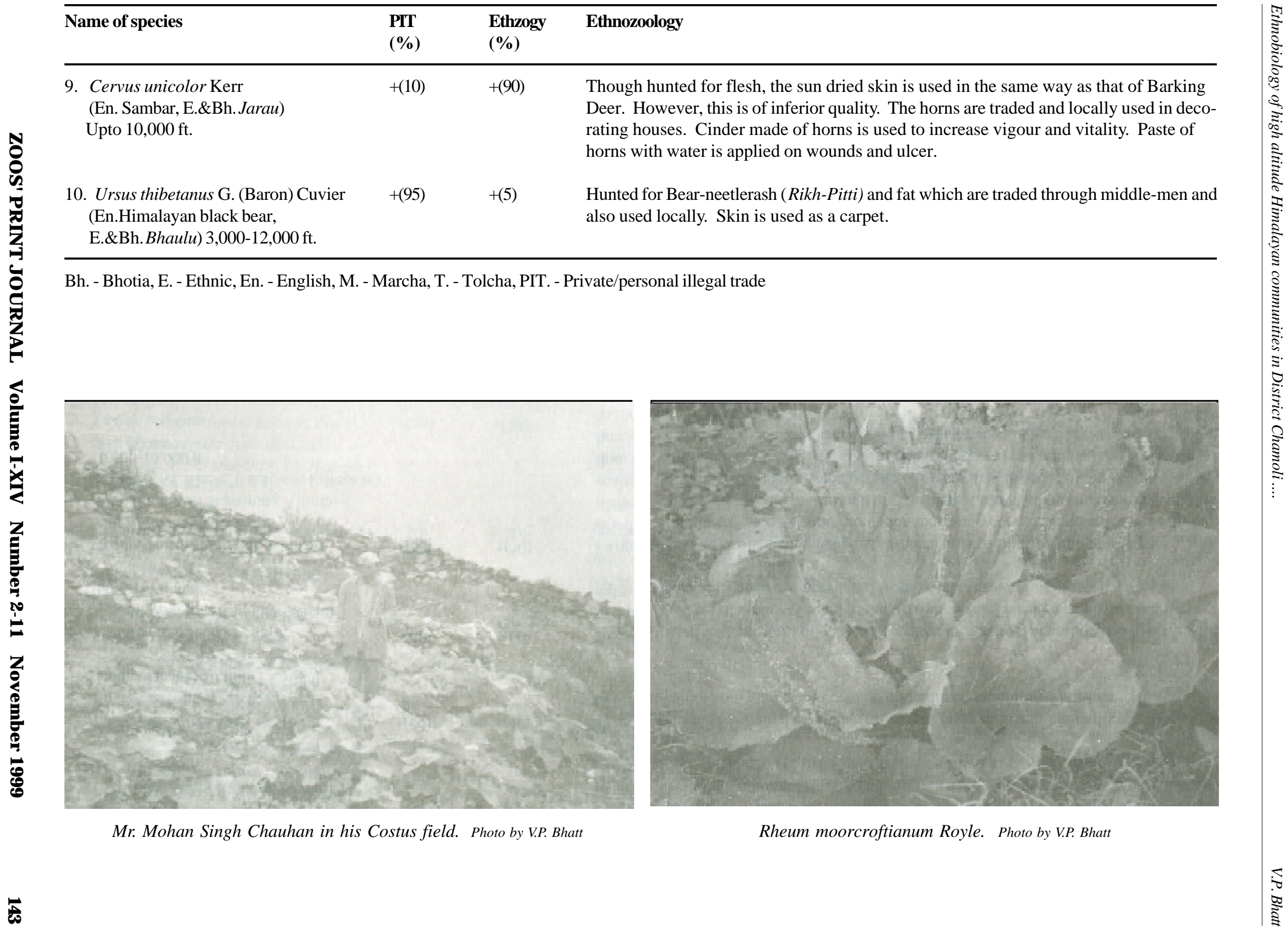




\begin{tabular}{llll}
\hline Name of species & PIT & Ethbny & Ethnobotany \\
& $(\%)$ & $(\%)$ & \\
\hline
\end{tabular}

1. Aconitum falconeri Stapf.

(E.\&Bh. Meetha; Ranunculaceae) $10,000-13,500 \mathrm{ft}$.

\section{A. heterophyllum Wall.ex Royle} (En. Atees root, E.\&Bh.Atees; Ranunculaceae) 10,000-13,500 ft.

3. A. violaceum Jacq.ex Stapf. (E.\&Bh. Meetha; Ranunculaceae) $10,000-14,000 \mathrm{ft}$.

4. Allium consanguineum Kunth Syn. A. Stracheyi Baker (En. Himalayan Seasoning Allium, E. Feren, M. Koch, T. Ladum; Liliaceae) $10,000-16,000 \mathrm{ft}$.

5. Angelica glauca Edgew (En. Himalayan Angelica, E. Gandrani, Bh. Choru; Apiaceae) 10,000-14,000 ft.

6. Arnebia benthamii (Wall.ex G.Don) I.M.Johnston Syn.Macrotomia benthamii (Wall) A.Dc. (E.\&M. Balchar, T. Laljari; Boraginaceae) $11,000-14,000 \mathrm{ft}$.

7. Dactylorhiza hatagirea (D.Don) Soo (En. Salep, E. Salampanja, Bh. Hatajari; Orchidaceae) $10,000-14,000 \mathrm{ft}$.
Externally used with mustard oil in curing back pain, sciatica, neuralgia and in the healing of sores. Very small amount (equal to the tip of a needle) is taken orally to cure tuberculosis. Goats and sheep are prevented from grazing leaves.

$+(60)+(40) \quad$ Dried roots are used against acute diarrhoea and fever especially in children. This is one of the main medicinal plants collected by nomadic communities for trade.

$+(40) \quad+(60) \quad$ Externally used with mustard oil in curing back pain, sciatica, neuralgia and in the healing of sores. Very small amount (equal to the tip of a needle) is taken orally to cure tuberculosis. Goats and sheep are prevented from grazing leaves.

+(50) Large quantities are collected in wild just in the vicinity of Bhotia summer villages. Locally dried aerial parts are used as condiments for seasoning curries, vegetables and similar dishes. Traded either locally or through middle men. Cultivated by some farmers on small scale in Niti Valley. In Jelum, some people cultivate it on the roof of their houses thatched with barks of Betula utilis (Bhoj patra) and covered with soil. These types of houses are especially made for the cultivation of this species. Dried flowers are considered as the Allium of first grade.

Small pieces of dried root and rhizomes are chewed to cure gastritis and constipation. Also used as condiments and seasoning agent. Traded locally and at Badrinath.

+ (50) Dried roots are mixed with mustard oil (app.50g./100ml.). This red oil is used to increase hair growth and as dye for grey hair. The oil is also useful in arthritis. Traded locally at Badrinath market (200 Rs./kg.).

Paste of the root is applied with water on deep cuts tocheck bleeding. Powder of the root (1/4 tea spoon) is taken with milk as rejuvenation tonic. Whole dried root is used in various tantric and religious rituals. Traded illegally, marketed at Badrinath (Rs.2000/kg.). 


\begin{tabular}{llll}
\hline Name of species & $\begin{array}{l}\text { PIT } \\
(\%)\end{array}$ & $\begin{array}{l}\text { Ethbny } \\
(\%)\end{array}$ & Ethnobotany \\
\hline 8. Jurinea dolomiaea Boiss. & $+(10)$ & $+(90)$ & Rootsarecollected
\end{tabular}

8. Jurinea dolomiaea Boiss.

Roots are collected to make incense sticks, used mainly as an adhesive agent rather than Syn Jurinea macrocephala (Royle) C.B; Clarke (E.\&Bh.Guggal/Dhoop; Asteraceae) 9,000-13,000 ft. MSL.

9. Juniperus indica Bertol.

Syn. Juniperus wallichiana Brandis Juniperus pseudo-sabina,Fish \&Mey. (En.Juniper, M.Bhitaru, T.Dhoop;

Cupressaceae) 9,000-14,000 ft.

10. Nardostachys grandiflora DC. Syn. Nardostachys jatamansi DC. (En.Spikenard, E.Jatamansi, Bh.Mansi; Valerianaceae) $10,000-16,000 \mathrm{ft}$.

11. Orchis habenarioides King \& Prantl. Syn Gymnadenia orchidis Lindl.

(En. Salep, E.Salampanja, Bh.Hatajari; Orchidaceae) 10,000-13,500 ft.

12. Picrorhiza kurrooa Royle ex Benth. (E.Katuki, Bh.Kaduwi;

Scrophulariaceae) $10,000-16,000 \mathrm{ft}$.

13. Pleurospermum brunonis Benth. Syn. P. densiflorum Benth (Bh. Tukker,Apiaceae) 11,000-16,000 ft.

14. Podophyllum hexandrum Wall ex Royle (0) Syn.Podophyllum emodiWall.

(En. Indian podophyllum,E.Ban-Kakri, T.Antond, M. Pa-Ghyanudi, Tempuli; (Berberidaceae) 10,000-14,000 ft. MSL.

15. *Rheum emodi Wall. ex Meissner

Dried roots and rhizomes are used as blood purifier, liver tonic and in acute fever, acidity and stomach pain. A small piece is left in water for a whole night, and in the morning taken orally for treating constipation and gastritis. Traded at Badrinath (Rs.300/kg).

+ (100) Collected by every Bhotia family and pastoral nomads for making incense. It is considered sacred as Nardostachys.

+(100) The pastoral nomads collect the ripe fruits to make a decoction which is used against diarrhoea in goats and sheep and in humans as well. The ripe fruits are also relished by the locals, alpine crow, Himalayan Pheasant Monal (Gallus gallus) and alpine mouse (E. Runda, M.Meet, T. Banmuso). There are hardly any natural habitats left in the wild for this species.

Paste of the dried roots with water and/or with cow's urine is applied on cuts, wounds and sprain but not on burns as suggested by Shah and Jain (1988) and Shah and Joshi (1971). A dye is extracted to colour home-spun woollen clothes. This is the actual Himalayan rhubarb used as the drug Revandchini in Ayurvedic preparations. Rare in occurrence. 


\begin{tabular}{llll}
\hline Name of species & PIT & Ethbny & Ethnobotany
\end{tabular}

(\%) $\quad(\%)$

obotany

16. *R. moorcroftianum Royle (E. \& T.Tantri, M.See; Ploygonaceae) $10.000-16,000 \mathrm{ft}$

17. Saussurea gossypiphora D.Don.

(E.Fan-kamal, Bh.Faina-kangol/kaunlo;

Asteraceae) Above 16,000 ft.

18. S. obvallata (DC.) Edgew.

(E.Brahm-kamal,Bh.Kangol/Kaunlo;

Asteraceae) Above 15,000 ft

19. Swertia chirayita (Roxb.exFlem.) Karst. (0) Syn. S. Chirata, Buch-Ham ex C.B.Clarke

(En.Chirayita, E. \& Bh.Chirauto

Gentianaceae) 5,000-9,000 ft.

\section{Taxus wallichiana Zucc.}

Syn. Taxus baccata, L.

sub.sp. wallichiana (Zucc.) Pilger

(En.Himalayan Yew, E. Bh. Thunyor,

Taxaceae) 9,000-14,500 ft.

21. Valeriana wallichii DC.

Syn. Valeriana jatamansi Jones.

(En. Indian valerian, E. Samoya;

Valerianaceae) 4,500-8,300 ft.

(0) $\quad+(100)$
The fresh stem and leaf bases are cut and steamed on the steam of cooking rice.

These steam-boiled pieces are ground with salt and chilli to make a chatni (sauce; a special dish of Bhotias). To cure constipation in children, paste of the roots with water is smeared externally around the umbilicus. A dye is also extracted from the roots. This species is not traded at all. This is common species perhaps due to high percent of natural regeneration.

+ Inflorescence is made into a paste with water and applied on severe burns. kept in houses to keep away evil spirits. Collected and marketed by some Sadhus at Badrinath.

Grown in every temple situated in high altitudes of this area, the inflorescence are collected in large quantities for decorating the idols and pilgrims receive the flowers as holy blessings of God. It is believed that when kept in the house, the flowers help in normal delivery.

+(100) Collected from the wild by local traditional medical practitioners (Vaidyas) and herb healers for making a decoction used against malarial and general fever and also as blood purifier. Habitat destruction is the main cause for its depletion. Very much confused with other species of Swertia.

Bark rather than leaves is collected for making Bhotia tea (jya). Paste of the bark and leaves with water is externally applied by the ethnic people for breast cancer (Doodh Baal) and if any domestic animal is suffering from canceral symptoms, bedding of leaves is prepared to cure the disease. Old trees are cut to make boxes, doors, containers (Parya), grain pounders and other domestic woodden items including pipe for traditional water mills. The arils are not edible as suggested by Singh et al.(1990).

A paste of the fresh roots is applied as an unguent (Bano) with other herbs during holy bathing in Hindu nuptial ceremonies. The roots are also kept in a box to protect clothes. In summer a bunch of roots and rhizomes is kept on a window sil to let the warm valerian wind to blow in. Traded illegally from some previously identified pockets. The cattle are prevented from grazing leaves in spring. The dried roots are Rs. $90 / \mathrm{kg}$. and leaves Rs. 22 /kg. at Ramnagar herbal mandi.

* Some villagers at Jelum use R.. emodi in place of R. moorcroftianum. Some scientists are also confused with the vernacular names Dolu and Archa. However, the name Dolu is used in Chamoli and Pithoragarh while Archa is common in districts Tehri and Uttarkashi for the same (former) species.

Bh. - Bhotia, E. - Ethnic, En. - English, M. - Marcha, T. - Tolcha, PIT. - Private/personal illegal trade 